\title{
15 \\ THE MODERN ERROR: OR, THE UNBEARABLE ENLIGHTENMENT OF BEING
}

\author{
Eugene Halton
}

It seems to me that man has what we call a human heart, but that he also has something of the baboon within him. The modern age treats the heart as a pump and denies the presence of the baboon within us. And so again and again, this officially non-existent baboon, unobserved, goes on the rampage.

(Vaclav Havel, 1986)

In order to convey what I mean by 'the modern error', let us consider what is meant by the term 'the modern era'. By the word 'modern' most people mean the twentieth century, especially when talking about art. Take, for example, the Museum of Modern Art in New York, which is renowned for its twentieth-century collection. 'Modern' in this sense used to function as a synonym for the term 'contemporary' in the first half of the twentieth century, but now connotes the art of the first two-thirds of the twentieth century.

A broader chronological sense of what is meant by 'the modern era' would include the industrial era, basically the development of mechanized industry in the nineteenth and twentieth centuries. Broader again would be the Age of Enlightenment, especially the rise of revolutionary governments, democracy and the Western project of 'liberty, fraternity and equality'. The theme of the Enlightenment is most often connected with the goal of a society ruled by reason and its laws, rather than by royal decree, caprice or irrational upsurges.

We can take a yet longer view of the modern era as synonymous with the rise of capitalism, or with the rise of scientific materialism in the West, and its establishment of a mechanical universe ruled by mechanical, physical law.

We can also take a sceptical view, as postmodernists have done, of the modern era as a delusionary culture which 'privileged' such concepts as individualism, progress, science and being, among others. In 'privileging' being, according to postmodernists, modernity falsely accorded 'essential' and 'natural' characteristics to what were merely the dominant conventions of the culture. Being, say the postmods, is insignificant, and significance, or 
signification, is either a convention rooted in the arbitrariness of linguistic communication or a transgression of convention. In my view this supposedly 'postmodern' view simply extends the modern tendency to denigrate being the passional relation to existence - in favour of knowing. Hence by my lights postmodernism is more a sign of the exhaustion of modernism than a genuinely new and non-modern outlook.

This brings me to my peculiar title: 'The Modern Error: Or, The Unbearable Enlightenment of Being'. I aim to suggest that the underlying premises of the modern era - e-r-a - are false in a way that carries catastrophic consequences. Despite the many genuine achievements of the modern world - which I for one would not want to live without - the spirit of modernity has been one which denigrated the basic conditions of human being.

The comedians Mike Nichols and Elaine May used to have a routine going back to their days with the Second City Comedy Club in Chicago, in which they would toss words back and forth which would qualify as 'cleans' and 'dirties'. For example, the term 'Lake Michigan' is a clean, while 'Lake Titicaca' - enunciated very slowly - is a dirty. 'Sword' is a clean, while 'rapier' is a dirty. Are you with me, dear reader? We can apply the same method to a number of terms in intellectual life today. The term 'public intellectual' is clearly a clean, while for many, the term 'tenured radical' is a dirty. Philosophy is regarded by many today as a dirty, while social theory is a clean.

There is, of course, a long tradition, going back at least to Marx's last thesis on Feuerbach, to call for the end of philosophy. But today anti-philosophical philosophers, such as Richard Rorty, to take a notorious example, gloatingly decry the very idea of the love of wisdom - philo-sophia - and the quest toward a comprehensive understanding which the term connotes, as obsolete. In this general mind-set, contingency, pluralism and social constructionism are cleans, while essences, foundations, experience and universals are all dirties. 'Reality' is a dirty while 'fiction' is a clean. The ' $\mathrm{I}$ ' is a dirty, and so is 'we'. An 'author' is a dirty, while a 'text' is a clean. 'The body', formerly a dirty, can be redefined as a 'text', and made into a clean. 'Local cultures' are clean, while 'humanity' is a dirty. 'Privileging' and 'valorizing' something is a dirty, while using the terms 'privilege' and 'valorize' as verbs is a clean. 'Postmodernism' is a clean, while 'modernism' is a dirty. 'Non-hierarchical multiculturalism' is a clean, while a 'canon' is a dirty. Both those who characterize certain people as 'politically correct' and those who are so characterized agree that it is a dirty. John Dewey used to be a dirty for most post-Second World War academic philosophers, but now that the 'public intellectual' has become a clean, Dewey has become a clean. Even more remarkably, Dewey, the philosopher who lamented what he termed 'the eclipse of community', has become a clean for many who also regard community as a dirty. Figure that one out!

Central to contemporary intellectual life is the assumption that 'the big picture', traditionally sought by philosophy, is a dirty, while 'little pictures' 
are clean. I wish to claim that fallible big pictures are not only still possible but are requisite for confronting the modern and postmodern world. Also central to intellectual life today, although more problematically, is the assumption that organic nature is a dirty, while culture is a clean.

When the term 'nature' is used in the context of ecology it can be put safely within a political context, and then regarded as a clean. But the idea that organic biology may have some direct and inward influence on persons, institutions, societies and civilizations, that human conduct cannot be completely reduced to socio-historical cultural constructions categorically distinct from nature - such an idea is a dirty, even if John Dewey, the newly reconstructed clean public intellectual, might have sought such a naturalistic basis for human conduct. That side of Dewey is declared a dirty, and consigned to the dungheap of history.

As Marshall Berman has noted in his wide ranging and provocative book, All That is Solid Melts into Air (1982), the terms 'modernity', 'modernization' and 'modernism' have different meanings and values associated with them. 'Modernization' is usually associated with the view that science, technology and rational values promote progress. 'Modernism' is usually associated with the kinds of art which erupted in the twentieth century, which seemed to fly in the face of the Western achievements of representation and perspective in painting, of tonality in music, of ornament in architecture.

Modernism is usually associated with the concept of the 'avant-garde', which links it with the idea of progress associated with modernization, even though many avant-garde movements were reactions against rationalization. Artistic modernism is generally acknowledged to have lost its grip on the arts. When we consider the emergence of twentieth-century modernism, it seems at first glance to be primarily a European phenomenon, at least up until the Second World War. We think of Picasso and Paris, and more recently, of Klimt, Kokoschka, Schiele, Schoenberg, Wittgenstein and others in Vienna, of Russian constructivism and the Bauhaus. These revolutionary movements emanated out of Europe rather than America, in my opinion, because the sheer weight of the past had become oppressive in Europe. This was not the case in America, for one thing, because there was much less of a past to discard. Serious art and serious, original thought also tended not to be supported in ways that valued artists and philosophers. Hence we have the phenomenon of the American 'isolato', as Melville called it, in contrast with European artists' circles.

This said, Melville himself is a remarkably early contributor to modernist literature, with Moby Dick penetrating as deeply into the modern heart of darkness as Dostoyevsky's The Brothers Karamazov and, almost one hundred years after Moby Dick, Thomas Mann's Dr Faustus. One can also argue that modern architecture was begun in Chicago, by architects such as Sullivan and Wright. But it really only emerged in a modernist movement in Europe: Chicago kissed its baby goodbye, in effect, and it returned as the monster of the 'international style' in the person of Mies van der Rohe years 
later, a rational system applicable anywhere, delocalized in its cosmopolitan aspirations, institutionalizing itself in gigantic ascetic skyscrapers of glass and steel.

But there is also an opposite tendency in the modernist movement against rationality and formalism, signalled by primitivism, Dadaism and other currents. Form-breaking, mercurial and transient qualities have been key elements of the modern experience, and remain entrenched in characterizations of postmodernism. In his 1918 essay, 'The conflict in modern culture', Simmel pointed out the significance of the form-breaking concept of life for twentieth-century culture. He saw in the rise of artistic expressionism and in the prevalence of Lebensphilosophie itself, especially philosophical pragmatism, a new cultural paradox. In Simmel's view human cultures are marked by an ever-present dialectical tension between form and life. Yet this dialectic between form and fluid vitality had reached a peculiar turning point by the turn of the century: the form of the twentieth century was revealing itself as formless life itself. Simmel drew attention to the paradox that life, inherently formless, was becoming the form of the age - a formless form. His examples included expressionism in art and pragmatism in philosophy. In Kandinsky's works of the period in which Simmel was writing, colour is liberated from form to become expressive in its own right. Jamesian pragmatism, with its elevation of vital existence over immovable truth, struck Simmel as a key indicator of the paradoxical transposition of life to form. One might add that Simmel himself, though still a formalist, drew from the same spirit of the time in turning to Lebensphilosophie. Unfortunately he did not see the other half of the paradox, the formalization of life itself, resulting in lifeless life. Instead of a dialectical tension between life and form, a strange inversion was occurring, eventually producing lifeless life and formless form, each, in effect, cancelling the other out instead of transforming it.

It is instructive to consider the ways the ethos of modernism sought a cleansing break with the past, one which was to uncover universal principles (for example, in international architecture, positivism and 12-tone music) and, freed from the dead hand of the past, also was to produce a radically original, brave new world. When we consider this ethos and how it was able to institutionalize itself in America after the war, we begin to find dim outlines of a larger narrative at work, one which is, in my opinion, only continued in postmodernism. That narrative is the dream of a purely rational world of freedom and equality and unlimited progress, a world in which increasingly automatic contrivances spun from the head of science and technology secure human autonomy. As that dream unfolded it released great and terrible energies and ideas. But as it came to its culmination in our time, it realized its diabolic inversion, which was present from its inception: a radical alienation of the human soul, body and mind from the organic conditions of being. This is what I mean to suggest by 'the modern error' and 'the unbearable enlightenment of being' (my apologies to Milan Kundera). Of special note is that the American institutionalization of modernism took 
place primarily through universities, where thinkers and artists could work securely in a protected environment, yet an environment increasingly dominated by the rational intellect, and its tendencies for specialized knowledge and technique.

The term 'modernization' has usually been more associated with the level of industrialization in the economy, as an index of progress, yet, like modernism in the arts, it has fallen into disfavour with the rise of potentially catastrophic ecological problems due, precisely, to 'modernization'. With these senses of the word 'modern' as a starting point, let us turn briefly to some of the ways the modern experience has been conceptualized by social theorists.

We can understand the modern era as the rise of capitalism and its consequences. Though Karl Marx seems to have become a downright dirty recently, and not only for the right, we can still view, with Marx and critical theory, the rise of capitalism as associated with the rise of individualism and the breakdown of traditions as binding forces in society. Robert Bellah, William Sullivan and their co-authors of The Good Society (1991) lucidly depict how John Locke's conception of primal individuals inherently separate from the institutions of the societies into which they are born, live out their lives and die, has fostered a culture in contemporary America which surrenders both individual autonomy and democratic institutions to automatism and unchecked corporate power and greed.

We can, with Max Weber, view the rise of a new ethos of rationality, associated with the capitalistic spirit but not limited to it. As opposed to Marx's optimism that capitalism would give way to socialism and communism in the inevitable unfolding of history, Weber foresaw the withering effects of bureaucracy which the modern ethos and its rationalism was leading toward, effects which the downfall of Communism has dramatized and which the immense social problems of the United States reflect.

We can also see the modern era from the unique perspective developed by Lewis Mumford, who saw modernity as the 'myth of the machine', the story of the successful rise and domination by the 'megamachine', a cultural belief system which developed a mechanical world view in its physical science, which eventually was taken to be the basis on which culture was constructed. What is unique in Mumford's perspective is that the modern megamachine, though idiosyncratic in world perspective, is not unique, but corresponds to the re-establishment of the ancient megamachine which was formed in the advent of civilizational structures. There, one saw the rise of centralized bureaucracies, of standing military organizations and mass killing warfare, and of the exalting of the king to divine or semi-divine status, as, for example, in Egypt, where the Pharoah was an incarnation of the Sun God.

With the rise of these civilizational structures, new energies crystallized in the establishment of centrally organized power, ranging from economic, political and religious bureaucracies to the harnessing of large-scale organized human labour. Civilized humanity discovered the secret of the ants and bees: how a division of labour could produce a populous and 
efficient social life. The great dream of civilizational life might be expressed as how an increase in forms of automata could create living conditions which might enlarge autonomy. Thus was born the spectre of human reason, the emanation to outward institutional form of the rational capacity, which increasingly displaced the non-rational but reasonable sources of institutions. And thus too, if we listen to William Blake and Mumford, was born the power of the human machine world, of mechanized order and stochastic contingency, which is completing itself - realizing its entelechy or perfection - in our time.

As Blake said almost two hundred years ago, 'The Spectre is the Reasoning Power in Man, and when separated from Imagination and closing itself as in steel in a Ratio of the things of Memory, It thence frames Laws \& Moralities to destroy Imagination, the Divine Body, by Martyrdoms \& Wars' (from 'Jerusalem'). Those who live by conceptual reason often devalue Blake by consigning him to the category of a 'romantic', meaning by romanticism some combination of excessive sentimentalism, individualism or nature mysticism. Yet he poses a serious critique of homo sapiens in the previous quotation and throughout his work. He is saying that Imagination is a deeper human capacity - poetically expressed as 'the Divine Body' than rational reasoning - poetically expressed as a secondary emanation or 'Spectre' - and that rational reasoning depends upon a living continuity with Imagination.

The separation of rational reasoning from Imagination - 'closing itself as in steel in a Ratio of the Things of Memory' - is expressed in a way similar to the metaphor used by Weber to describe the developmental logic of instrumental rationality in modern culture: a steel-hard casing or 'iron cage'. But where Weber's negative metaphor served to depict the consequences of what he took to be the inherent closed-ended logic of modern rationality, Blake's poetic expression explicitly denies that rationality is a fully autonomous capacity, and shows the way to conceive of rationality as an open-ended capacity which depends upon something greater than itself Imagination - in order to function reasonably. To a modern or even postmodern rationalist, however, the idea that something as wispy sounding as 'Poetic Imagination' can be foundational to rationality must seem like a fanciful delusion. Perhaps it is. And yet I beg the reader's patience, for I am claiming that Blake's words derive from an anthropology that resonates with the scientific philosophy of Charles Peirce, the founder of pragmatism no less, and the social philosophy of Mumford, one which could contribute to a transformation of social theory today. It is an anthropology which allows that intelligence is projective before it is reflective, and that conjecturing remains a more basic capacity than criticism, a capacity which is the very ground on which criticism stands.

These views, especially Mumford's, have much still to say about the modern predicament, and the postmodern post-predicament. Let me also suggest another angle on viewing the modern era, which I believe offers some insights into postmodernity. My own approach is to view the modern 
era as cultural nominalism, a split world view in which only individual things are regarded as real and thoughts are regarded as conventions. I am not claiming that the philosophy of nominalism opened up by William of Ockham - which was known as the via moderna - caused the modern era, but simply that it was the intellectual manifestation of the emerging modern era. By looking at the modern era as cultural nominalism certain seemingly opposed views coalesce into an image of modernity as 'the ghost in the machine'.

Weber assumed this split of 'the ghost in the machine', the inherited legacy of Descartes and Kant, as a progressive development, and it pervaded his own thinking on political life and the social sciences. The mechanical world picture may have been a historical reality, but it was by no means historically necessary for the rise of sophisticated science. In its false materializing of the object and false etherealizing of the subject, the mechanical world represents a progressive abdication of human autonomy to the automaton. It must ignore generative, incarnating mind in favour of either objective mechanism or subjective, incorporeal spirit.

Weber claimed that action has to do with subjectively intended meaning; yet one need not begin with isolate subjects subjectively 'intending' meaning, nor is human conduct exhausted by intentions. An alternative view is to see conduct as fundamentally social and derivatively 'subjectively intended'. One can still champion the subjective as an ineradicable element of human conduct and institutions, but the subjective expressions and intentions of the human personality are not divorced from the social medium, as Weber thought. The passionate and 'intending' self is continuous with the communicative signs of the social medium, no matter how autonomous it may be.

One of the consequences of the neo-Kantian perspective shared by Weber and Simmel, as well as many contemporary theorists, is a view of meaning as a human faculty conferred on the chaos of experience. As Weber (1904/ 1949: 81) said: " "Culture" is a finite segment of the meaningless infinity of the world process, a segment on which human beings confer meaning and significance'. Simmel sounds even more contemporary in his 1911 essay, 'On the concept and tragedy of culture' (1911/1968: 33) where he says:

Ocean and flowers, alpine mountains and the stars in the sky derive what we call their value entirely from their reflections in subjective souls. As soon as we disregard the mystic and fantastic anthropomorphizing of nature, it appears as a continuous contiguous whole, whose undifferentiated character denies its individual parts any special emphasis, any existence which is objectively delimited from others. It is only human categories, that cut out individual parts, to which we ascribe meaning and value. Ironically, we then construct poetic fictions which create a natural beauty that is holy within itself. In reality, however, nature has no other holiness than the one which it evokes in us.

Simmel's Kantianism, beautifully expressed here, assumes the modern ghost-in-the-machine perspective in denying that nature possesses qualitative differentiation (or form, in Kant's language) independent of human 
categories. Clearly humans do construct 'poetic fictions' of nature, given that being human means being inescapably anthropomorphic to at least some degree. But admitting this does not rule out the possibility that human life, so rooted in the fantastic symboling processes of dreaming, ritual life and language, may not itself be a 'poetic fiction' evoked by nature. Nor does it rule out the possibility that Kant's dualistic view of nature and knowledge may itself be a poetic fiction of the modern mind.

From my perspective, the Lockean/Kantian view that all natural beauty is but a 'secondary quality' of subjective human perception rather than a genuine transaction between a quality of nature and a human perceiver, that faculties of knowledge spring unevolved and full-blown from human heads alone, rather than as tempered achievements of creatures who evolved in transaction with the inherent forms of nature, strikes me as the modern fantastic anthropomorphizing of nature into the ghost in the machine. Though Simmel, and more particularly Weber, saw more deeply into the ever-darkening consequences of modern rationalization than many of their more optimistic contemporaries, neither saw the possibility that the very process of rationalization was itself responsible for conferring meaninglessness on the world process, thereby reducing it to a sensory manifold. That is, they could not see that the Kantian perspective might itself be a product of faulty and by no means inevitable development of rationalization.

Simmel, standing within the Kantian orbit, noted the parallel emergence of objective nature and subjective freedom over the past few hundred years:

Thus we can observe the distinctive parallel movement during the last three hundred years, namely that on the one hand the laws of nature, the material order of things, the objective necessity of events emerge more clearly and distinctly, while on the other we see the emphasis upon the independent individuality, upon personal freedom, upon independence [Fürsichsein] in relation to all external and natural forces becoming more and more acute and increasingly stronger. . . . Whatever difficulties metaphysics may find in the relationship between the objective determination of things and the subjective determination of the individual, as aspects of culture their development runs parallel and the accentuation of the one seems to require the accentuation of the other in order to preserve the equipoise of inner life. (Simmel, 1900/1978) ${ }^{1}$

With characteristic perspicacity, Simmel reveals an unexpected correlation in the making of the modern world, one which released previously undisclosed human potentials.

Yet although these are distinctive achievements of the modern era - the mechanical view of nature and the release of the personality (exemplified, as Milan Kundera points out, in the emergence of the novel), they came at what we must now realize was a terrible cost. What Simmel was celebrating as a modern epiphany might also be characterized as the manifestation of the split-brain world of a mechanized nature severed from organic purpose and a spectral world of subjectivity sundered from nature. The legacy of the bifurcated worlds of Descartes and Kant culminated in extreme forms of 
objectivism and subjectivism in the twentieth century, with deadly consequences which we can no longer ignore. The Kantian view that 'facts' are objective and values are subjective, which both Simmel and Weber inherited, ultimately gave licence to the diabolical release and massive expansion of powers which exceeded human purpose or limitation: let us not forget that the atomic bomb is one of the great epiphanies of the modern world, and that German Innerlichkeit and Kultur could easily turn into the god-like view that I can do whatever I feel inside, apart from otherness, a view which reached its extreme terminus in Adolph Hitler.

This dark side of the modern epiphany was expressed quite clearly by H.G. Wells in his book The World Set Free, which detailed a world nuclear war which involved what Wells called 'atomic bombs'. That book was published in 1913, before the first outbreak of world war!

\section{Progress, modernity and disintegration anxiety}

The final downfall of most of the European Marxist-Leninist regimes at the close of 1989 signalled the death-knell of the nineteenth-century modernist dream of communism. Though Stalinism and its predecessor, Leninism, represent crucial breaks from Marx's critical programme - most fundamentally in their ruthless repression of Marx's call for 'relentless criticism of all existing institutions' - Marx himself is by no means immune from the failures of Marxism. His view of an inevitable grand march of history, his allowance of a transitional 'dictatorship of the proletariat' phase, his relatively uncritical attitude toward centralized state power and machinery, all left great gaps through which gross tyranny could and did march.

Yet despite the obvious failings of Marxism, Marx remains an astute social critic and historian, and many aspects of his critique of capitalism, the machine and modern life, as well as his rooting of human life in experience or practice, when shorn from the vision of an inevitably progressing history and an all-powerful state, will remain valuable resources to social thought. One can see Mumford's concept of the megamachine, for example, as a more refined development of the critiques of the machine given by Marx, Samuel Butler and others, freed from the unnecessary utilitarian restrictions of Marx's materialism.

If Marx had been able to rid himself of an inevitable conception of history and an overly materialized conception of human conduct, 'historical materialism' might have provided a much needed corrective to the reified views of nature and etherealized views of mind which characterize the Kant-dominated tradition of social theory, including Weber, Durkheim, Simmel, Parsons, Habermas and others. Yet its faith in inevitable and revolutionary progress appears as a quaint utopian fantasy after the catastrophic destruction of lives, cities and the moral fabric of Western civilization and world culture witnessed in the revolutionary twentieth century. For we have witnessed what Henry Adams sensed so accurately in 
his remarkable letter to Henry Osborn Taylor in 1905. Note that this letter was written within about a year in which Einstein discovered relativity, Picasso and Braque invented cubism and Stravinsky released the daemonic energies of The Rites of Spring. This historian and humanist and descendant of American Presidents said:

The assumption of unity which was the mark of human thought in the middle-ages has yielded very slowly to the proofs of complexity. The stupor of science before radium is a proof of it. Yet it is quite sure, according to my score of ratios and curves, that, at the accelerated rate of progression shown since 1600 , it will not need another century or half century to tip thought upside down. Law, in that case, would disappear as theory or a priori principle, and give place to force. Morality would become police. Explosives would reach cosmic violence. Disintegration would overcome integration. (Adams, 1905)

Adams sensed the revolutionary social implications of the increasing release of power brought about by modern materialism. In the course of the 'century of progress', law did give way to force, in the name of 'Realpolitik' and technological progress. Morality did become police as police states proliferated throughout the world, employing huge armies and centralized secret police institutions, and ever more sophisticated weaponry, all done frequently behind the facade of a 'democratic' republic. Explosives did reach cosmic violence, with all the implications that 'dreamers' such as Adams or H.G. Wells predicted and that 'realistic' scientists and politicians were not prepared to meet. Disintegration did overcome integration, as the very 'successes' of modern societies created disastrous consequences which we have yet fully to face. Consider the denial involved in Mikhail Gorbachev's statement in 1992 after the Soviet Union was dissolved:

I am entirely certain that its death [Stalinism] does not affect socialism itself. The idea of socialism lives on, and it is my feeling that the quest - the desire to experiment and to find a new form for putting the socialist idea into practice - is ongoing . . . this quest affects not only our country (where a phase of history well known to us all took its start and ran its course) but the entire world, including the capitalist countries. (Gorbachev, 1992)

A 'phase of history' which 'ran its course': what bloodless euphemism. Communism was a deadly phase of the era of dehumanizing materialism in which we are still living, and it was that materialism and its tendency to elevate power over purpose which was the root of the problem, not simply bad Stalinism versus good socialism.

In America alone, the birth of the atomic age coincided with the creation of an arrogant military welfare state whose relentless test detonations of 'bombs of cosmic violence' up through the early 1960 s will have killed more Americans - current estimates are at least 300,000 deaths due to radioactive fallout - than the Korean and Vietnam wars combined, not counting the scores of thousands of contaminated military personnel, uranium miners and American families who lived near the bomb-making plants. Deliberate deception was employed by the US government against the American public 
and any scientists courageous enough to release information showing the deadly probabilities.

A flood of materials was released around 1990, corresponding to the end of the Cold War, which demonstrated conclusively the ways American Cold War policy, in the name of 'national security', subverted the requirements of public criticism for a viable democracy. Thousands of American families living near bomb-making factories and reactors, such as those in Fernald, Ohio, and Hanford, Washington, were exposed to appallingly high levels of radiation while the government of the US officially employed deception by claiming that there was no health hazard - even though it very well knew the dangers (see Halton, 1990). Likewise, the USSR probably killed at least as many of its citizens before Chernobyl through infantile handling of cosmic energies as the US military-industrial-academic complex did, not even counting its lethal attitude toward other forms of environmental pollution.

In his remarkable New Year's Day, 1990 speech, Vaclav Havel, who went from being a prisoner to becoming the President of Czechoslovakia in a matter of months, decried the way that Communism had turned people into 'the means of production'. He went on to say that 'we', the Czech people, are not simply victims, but have also participated in the little lies which allowed the 'monstrous, smelly machine' of Communism to keep on rolling. In other words, it is not sufficient to point the finger at the other; one must also include the possibility of self-criticism. Clearly the Communist machine was a slave state in contrast to America. Yet the evil Communist machine did not exhaust the evil of machine-like ways of thinking, despite the gloating of those in the West who celebrated the 'victory' of democracy and capitalism over Communism. Havel's words also carry a universal significance beyond their immediate context which are directly applicable to America and its arrogant national security military machine.

Despite the end of the Cold War, there has been little serious consideration of the proper limited context of what Dwight Eisenhower called the 'military-industrial complex' in a democratic republic. The irresponsible little Dr Strangeloves and their minions continue to dictate vital decisions affecting public life, immunized from public criticism. The reification and deification of nuclear power by the US and the USSR in the Cold War era, as well as the specific targeting of whole civilian populations by all of the great 'enlightened' modern superpowers, are key symbols of the descent into rational barbarism which Adams forewarned. As Nietzsche said, 'We moderns, we half-barbarians. We are in the midst of our bliss only when we are most in danger. The only stimulus that tickles us is the infinite, the immeasurable.' What better symbol of immeasurable power, what better materialization of the infinite has the modern world produced than the cult of nuclear bombs. In the bowels of the deadly military bureaucracies of the superpowers, under pure and total rational control, sat the tens of thousands of mechanical nuclear Calibans, ready at the push of a button to wreak the extermination of the biosphere if 'rationality' required it of them. 'We moderns, we half-barbarians.' 
Though we humans possess rationality, we are not rational beings and cannot become rational beings. Or let me modify that. The moment we truly become rational creatures is the moment when Ahab is lashed to the whale, when he, as the rational isolato subject, attains a final unity with the narcissistic object of his rationalization, his death. It is the moment of Raskolnikov's rational murder. That moment of the realization of the rational creature is the 'interesting age' in which we now are living.

We humans are passionate beings, whether we are modern workers in a rationalized factory or computer terminal, or Realpolitik calculators planning how to maximize our individual strategic interests, or scientists enquiring into the origins of the physical universe, or philosophers enquiring into the sources and ends of public life. We are beings of passion currently possessed by a singular passion for being rational. This rational passion, having exalted itself above creation in the name of 'God', 'Science', 'Reason', 'Critical theory', 'Modernity' and even, in unconscious selfalienation, 'Postmodernity', has blinded its adherents to the inner community of passions which are necessary to human sanity, and to the passional relation to the outer world of nature and experience. In the quest to attain universal intellect at any expense, we have committed the 'Unpardonable Sin', as Hawthorne put it in his short story Ethan Brand, of rationally possessed hubris, and have become severed from the universal 'heart-throb' of humanity. We moderns have become the fiendish Frankenstein monsters, Ethan Brands, Ahabs, Raskolnikovs, Mr Kurtzs and Adrian Leverkühns, presciently felt and imagined by those writers sensitive to the drift of modern culture.

The contemporary intellectual landscape is still dominated by those who believe that all we need to do is improve our critical rationality, science or technology, or to include multiple 'modes of authority' in our methods and theories. Yet, as Coleridge said, 'deep thinking is attainable only by a man of deep feeling' - today, of course, we would say 'by a man or woman of deep feeling' - and those who, living from the head alone, have lost the capacity to feel deeply are not likely to point the way toward a renewal of thought and culture.

Let me emphasize that I am not rejecting rationality per se, but simply the dominant tendencies of modern culture toward an ever more rational world. One of my basic premises is that the progressive development and release of rational capacities in modern culture and its institutions was only possible because of the legacy of the many forms of non-rational reasonableness embedded in Western civilization, a legacy by no means obsolete. In its ever greater expansion the rational mind increasingly devalued that which was not rational, and claimed that reason was synonymous with the rational. It was only able to do so, in my opinion, because of the rich, hybrid compost of organic intelligence on which it was based and which fuelled it, a reasonableness developed out of pre-Western, non-Western and precivilizational, even prehistoric sources. Those patterns of ritual expression and forms of feeling in the human constitution, such as dreaming, play and 
intense mother-infant bonding, reach back to deeply embedded biological sources - to pre-human and ecstatic mammalian sources - which were pivotal to the emergence of human beings and which continue to animate human conduct at the highest levels as well as the lowest (Halton, 1992, 1995).

The casting off of archaic culture, of traditional customs, mores and beliefs, of localized community, in the development of modern culture not only produced positive energies in the development of the modern autonomous self, but also had the unenlightening consequence of jettisoning the checks and balances of the human person, leaving the individual much more dependent on singular sources of socialization. 'Enlightenment' was supposed to replace the chaotic dark regions of the mythologizing psyche with sober modern reason, a project which neglected the possibility that mythic narratives might be expressions of a deeper relatedness with the powers that move humans than rational consciousness can touch. As Havel has put it:

Yes, when traditional myth was laid to rest, a kind of 'order' in the dark region of
our being was buried along with it. And what modern reason has attempted to
substitute for this order, has consistently proved erroneous, false, and disastrous,
because it is always in some way deceitful, artificial, rootless, lacking in both
ontology and morality. It may even border on the ludicrous, like the cult of the
'Supreme Being' during the French Revolution, the collectivist folklore of
totalitarian systems, or their 'realist', self-celebrating art. It seems to me that with
the burial of myth, the barn in which the mysterious animals of the human
unconscious were housed over thousands of years has been abandoned and the
animals turned loose - on the tragically mistaken assumption that they were
phantoms - and that now they are devastating the countryside. They devastate it,
and at the same time they make themselves at home where we least expect them to
-in the secretariats of modern political parties, for example. These sanctuaries of
modern reason lend them their tools and their authority so that ultimately the
plunder is sanctioned by the most scientific of world views. (Havel, 1986:160-1)

Consumer culture today is the chief socializing agent of the modern ghost in the machine, promising freedom and autonomy and immediate gratification while relentlessly colonizing both the civic community and the very structure of the self, from infancy on, like a retro-virus: a retro-virus which says, 'Buy me, drink me, eat me, dream me, desire me, and you will be yourself'. In the virtual reality of consumption culture anything goes if people will buy it, only the real cost for the delusion of endless possession is a loss of self-possession. The endless parade of consumptive fantasies becomes a way of life: the self can be endlessly redescribed, like new clothing. Between the Big System and pure chance contingencies stands the hollow self, with its glorious hypertrophied freedoms to choose and idealize, unburdened by its organic needs and limitations, by spontaneous empathy, or by purposes or commitments which transcend its singular existence. If, as Marshall Berman (1982) points out so well, Faust was the embodiment of the myth of development and modernization, postmodern Post-Faustian Person, driven by the irrational march of rational images and fantasies 
instead of the Grand March of history, is perhaps the logical terminus of the Faustian myth: the complete colonization of the inner life of humanity and the 'wide world outside' by the ghost in the machine.

\section{Re-attuning humankind}

Berman has claimed that we need to live the modern project more fully to realize its potentials, but I disagree. People did not fail modernism, as Berman seems to imply, modernism failed people, because of its unbalanced premises. The modern era has indeed bequeathed many valid potentials for human life, but to realize them a new civilizational context is required.

The future of human development at this point in history does not hinge on becoming more rational or, in the name of pluralism, more arbitrary, or on the blank postmodern carnival of all-purpose contingency, but on reharnessing rationality to its humane and cosmic moorings. In the fallible big picture I am suggesting, critical consciousness, which it was the virtual task of the modern era to cultivate - and perhaps the axial age up to the present - is fused with those deeper, tempered forms of reasonableness, the biosemiotic capacities through which we became human in the first place. The seemingly scientific term 'homo sapiens' becomes revealed as an artefact of the age of knowledge, for being human involves feeling, dreaming, experiencing, remembering and forgetting, and not simply knowing. Humans became human, in my view, by transmuting feeling into communicable form, by transforming those ancient biological mammal characteristics of mother-infant nurturance, play and rapid eye movement (REM) dreaming into social forms. Through such forms - dramatic ritual, the art of language, the languages of art and myth - emerging humans learned to become humans by communicatively comprehending the joys and sufferings of life. The ritualized expression of these capacities not only helped turn us into humans, with all of our fantastic diversities, visions and destructiveness, but remains, in personal, institutional and civilizational forms, the basis for the further development of the most sophisticated human endeavours. Emotions can develop or atrophy, both individually and institutionally, and can range from fleeting sensations to instinctive proclivities whose forms, however variously expressed, remain deeply engrained aspects of being human. The biological need of an infant to bond with its mother is one part of our primate heritage which is crucial for the emergence and development of the self. No matter how conventionally social and gender roles may be constructed, the stubborn fact remains that infants and toddlers require empathic mothering, however a mother may be defined.

The claim that there are influences and limitations upon human conduct which transcend current norms, local traditions and even human history, is an idea which does not find much favour in the contemporary atmosphere of rampant relativism, with its Rortys and Lyotards, its deification of contingency, its narcissistic scorn for experience as an irreducible mode of 
being. Charles Peirce's view that rationality remains an immature capacity whose further development involves its dependence upon, and ultimately its coalescence into, the extra-rational biosemiotic sources of concrete reasonableness, is utterly at odds with Habermas' vision of human development as the perfection of rationality, and with the pervasive, uncritical biophobia of contemporary thought. Why is it that supposedly critical thinkers fear critically reconstructing the received mechanical picture of nature, which remains inadequate to account for the rise of human purpose?

In his theory of 'communicative rationality' Habermas, supposedly a 'critical theorist', never thinks to criticize the assumption that rationality must be pre-eminent in human development. The acknowledgement of deep human passions, of the spontaneity of the human soul in its diverse expressions, flies in the face of most leading contemporary theories, with their effete disparagement of feelings, sentiments and passions as reducible to conceptual forms of legitimation or convention. These theories reify the emotions as supposedly outside of mediation, and then recite the litany of how everything is socially mediated. These theorists refuse to consider the possibility that passions or emotions are themselves inherently social modalities of signification embedded in, but not reducible to, conventionalized signification. Thus, in postmodern dress, they mindlessly repeat the basic premises of cultural nominalism which are traceable to the rise of philosophical nominalism: all meaning is either a convention or a contingency. This neat dichotomy, with the extreme relativism which usually accompanies it, is simply too narrow.

When seen in this light, the seemingly benign postmodern, post-factual, post-rational world where there are no truths or facts but only conventions and language games, reveals its corrupt consequences. When a Stanley Fish or Richard Rorty says that everything, including truth and goodness and beauty is a matter of 'socialization', taking, I might add, the process of socialization in the most banal sense of automatic internalization of norms, when they or James Clifford or other postpeople say that experience is but a 'mode of authority', the possibility of a public life, wherein fallible standards of discrimination, judgement, excellence and justice form the fabric of the good life, must give way sooner or later to direct power: morality becomes police, and integration gives way to disintegration. Contemporary theory and philosophy provides the groundwork for such a postworld.

The nominalistic premises of the modern age, which remain uncritically assumed by both Habermas and Rorty, and by those who believe that human social life is solely a conventional construction, urgently need to be overhauled through an imaginative realignment of humanity's place in the cosmos. Such a realignment involves opening social theory and philosophy to the public dimension, but it also involves opening the public dimension of social thought to the roots and limits of nature and world culture. Whether we will it or not, we are in the midst of making a world civilization, and the contemporary litany that theory can only be local, though not without its merit, is also a form of nearsightedness which remains blind to the 
significance of translocal norms and the bearing of those norms on local culture (not to mention that the assertion that theory must be local is itself not locally grounded and seems to claim the status of a universal).

The time has come to find a new way of renewing reason, a project requiring a transformation of values and outlook as vast as those which took place in the axial age or the modern age. ${ }^{2}$ The renewal of reason will involve opening the gates to the entire historical and prehistorical heritage of humankind, to renew the archaic values of family, household, neighbourhood and local community and the sympathetic relations they engender, to renew those organic and communicative essences of play, dreaming and mother-infant nurturance which are our human-mammalian legacy and crucial for the development of the spontaneous self, and also making a life-sustaining world culture with self-critical institutions capable of supporting and protecting the vitality of local ways. By actively cultivating such a 'big picture', we undercut the one already in place, in order to recontextualize rationality and to reactivate the precious roots of reason which the modern age claimed to have outgrown.

It is no exaggeration to say that the dominant contemporary theories of meaning advocate a thoroughly post-biological image of humankind (some, such as Derrida, even callowly terming themselves anti-humanist, seemingly oblivious to the positive virtues of the humanist tradition). And in our 'post-rational', 'postmodern', 'post-' culture, post-biological is taken to be a positive achievement, instead of the extreme form of self-alienation that it really is. Those who break the great taboo against mixing nature with culture tend to be looked upon with scorn and perhaps embarrassment by the majority of contemporary theorists. In this scorn and embarrassment, I claim, one sees the effete rational intellect, unwilling to confront critically its own extra-rational context.

With shrunken hearts and swollen, talking heads, the weird parade of anti-naturalists - the Stanley Fishes and Richard Rortys, Jürgen Habermases and Arnold Gehlens, radical feminists and conservative rational choice theorists, multiculturalists and defenders of the Western Civilizational Enlightenment - march in unquestioned lockstep unison. Because of these uncritical attitudes toward the received mechanical picture of nature by supposedly critical theorists, a social theory rooted in organic life and human passion, such as that which I am proposing, would undoubtedly be seen as obsolete by those leading theorists who have proudly and arrogantly severed the possibility of connections between their theories and biological life. Yet a biosemiotic social theory, capable of encompassing both the varieties and contingencies of human signification and the organic needs, limits and transformative possibilities of the living human being in his and her social, political and economic worlds, forms a profound critique of contemporary theory and contemporary life, and of the spirit of mechanized, depersonalized subjectivism which informs both.

We can pity poor modern man or woman, who conceives the universe to be a machine or a cybernetic system, or an unreal convention, who conceives 
his or her own mind and brain to be a machine. The human personality can be reduced to a mechanical or material basis, only all that is most human must be denied or bleached out. We can pity poor postmodern person, who can at best conceive of himself or herself as a broken machine, or as a 'text', or as an electronic component of a 'virtual reality'. These postmodern versions bespeak the realization of a thoroughly dehumanized world, in which all human attributes, especially emotional warmth and empathy, have vanished. But more than pity is required, for we are all of us implicated in the tragedy of modern life. Without a deep empathy for fellow moderns and postmoderns, ranging from our immediate life-situations to the large panorama of modern civilization in all of its diverse forms, and without self-empathy for our inescapable participation in this tragedy, we can too easily stand aloof while pretending to simply wipe the slate of history clean again. The myth of the machine, realizing its perfection in the electronic 'virtual reality' that is contemporary life, resonates ominously with the description of the anxiety of the disintegration of the self given by psychoanalyst Heinz Kohut:

What leads to the human self's extinction . . . is its exposure to the coldness, the indifference of the nonhuman, the nonempathically responding world. It is in this sense, and in this sense only, that we may say that disintegration anxiety is closer to the fear of death than to what Freud designated the fear of loss of love. It is not physical extinction that is feared, however, but the ascendency of a nonhuman environment (e.g., of an inorganic surrounding) in which our humanness would permanently come to an end. (Kohut, 1984:18)

We must find the means to correct the mistaken premises which form the modern error. In my view this task requires a fundamental transformation of the modern world view rather than piecemeal change, because piecemeal change will amount to too little, too late. In the name of freedom and knowledge, the modern era gave birth precisely to the non-empathically responding world Kohut describes, the schizoid ghost in the machine which now threatens to dissolve our humanity and the natural world. It is time to begin to body forth a new world view and world civilization, new ways of living both locally and globally in harmony both with outer nature and the nature within us, while preserving the genuine achievements of modern civilization, such as human rights, and private and public freedoms, as well as rediscovering the lost resources of the human past and new ways of joining them to the present. Without the hope of such a thoroughgoing transformation, we are likely to continue to go the way of the earth's ozone shield into corrosive self-extinction.

\section{Notes}

1. See also Gianfranco Poggi's Money and the Modern Mind: Simmel's Philosophie des Geldes (1993), where he argues that Simmel views modernity as an epiphany. Poggi quite accurately analyses Simmel's Kantian idea that truth is relative, that is, is a relation of representations, and why this should be taken as another manifestation of the superiority of modern over pre-modern thinking. He ignores the dark side of the modern 'epiphany', such as 
the simultaneous emergence of the Absolutist state, from the Baroque kings to the 'Big Men' of twentieth-century totalitarianism. In celebrating the modern over the premodern, one must ask how the modern police state is superior to the ancient Greek polis. Similarly, positivism is especially characteristic of the last century and must be reckoned with as a modern achievement which punctures the presumed superiority of modern thought.

2. The axial age, a time period beginning roughly around $600 \mathrm{BC}$, marked the emergence of the universal religions, such as Zoroastrianism and Buddhism and, later, others such as Christianity, Mithraism, Manichaeism and Islam, and also the development of a new kind of person and a new kind of community. The term 'axial age' is associated with Karl Jaspers, but Lewis Mumford also formulated the concept independently at about the same time, in the late 1940 s, and claims that both were preceeded by J. Stuart Glennie about fifty years earlier. As Mumford says in his book, The Transformations of Man (1956):

The central change brought in by axial religions is the redefinition - in fact the recasting - of the human personality. In that act, values that emerge only in the personality replace those that belonged to institutions and institutional roles. The new feelings, emotional attachments, sentiments are now incarnated in a living image, that of the prophet.

In Mumford's view the rise of the axial personality marked an opposition to and compensation for the bureaucratic civilizational structures.

\section{References}

Adams, Henry (1905) 'Letter to Henry Osborn Taylor, January 17, 1905', in The Letters of Henry Adams, Vol. 5: 1899-1905, edited by J.C. Levenson, Ernest Samuels, Charles Vandersee and Viola Hopkins Wimmer. Cambridge: Belknap Press, 1988, pp. 627.

Bellah, Robert, Madsen, Richard, Sullivan, William M., Swidler, Ann and Tipton, Steven M. (1991) The Good Society. New York: Alfred A. Knopf.

Berman, Marshall (1982) All That is Solid Melts into Air. New York: Simon \& Schuster.

Gorbachev, Mikhail S. (1992) 'No time for stereotypes', op-editorial, New York Times, 24 February.

Halton, Eugene (1990) 'Cold War's victims deserve a memorial', op-editorial, New York Times, 10 March.

Halton, Eugene (1992) 'The reality of dreaming', Theory, Culture \& Society 9: 119-39.

Halton, Eugene (1995) 'The cultic roots of culture', in Bereft of Reason. Chicago: University of Chicago Press.

Havel, Vaclav (1986) 'Thriller', in Vaclav Havel or Living in Truth. London: Faber \& Faber.

Kohut, Heinz (1984) How Does Analysis Cure? edited by Arnold Goldberg with Paul E. Stepansky. Chicago: University of Chicago Press.

Mumford, Lewis (1956) The Transformations of Man. New York: Harper \& Row.

Poggi, Gianfranco (1993) Money and the Modern Mind: Simmel's Philosophie des Geldes. Berkeley: University of California Press.

Simmel, Georg (1911/1968) 'On the concept and tragedy of culture', in Georg Simmel: The Conflict in Modern Culture and Other Essays, translated and edited by Peter Etzkorn. New York: Teacher's College Press.

Simmel, Georg (1900/1978) The Philosophy of Money, translated by Tom Bottomore and David Frisby. London: Routledge \& Kegan Paul.

Weber, Max (1904/1949) 'Objectivity in social science and social policy', in The Methodology of the Social Sciences: Max Weber, translated and edited by Edward A. Shils and Henry A. Finch. New York: Free Press. 